\title{
МОДЕЛЮВАННЯ СИСТЕМИ УПРАВЛІННЯ ЗАКЛАДОМ ЗАГАЛЬНОЇ СЕРЕДНЬОЇ ОСВІТИ 3 ВИКОРИСТАННЯМ ЦИФРОВИХ ОСВІТНІХ ТЕХНОЛОГІЙ
}

\author{
Павло Правдивцев \\ кандидат економічних наук, \\ старший викладач кафедри управління та адміністрування, \\ Донецький обласний інститут післядипломної педагогічної освіти, \\ м. Краматорськ, Україна \\ ORCID ID 0000-0002-1593-2412 \\ p.pravdivtsev@ippo.dn.ua \\ Тетяна Колган \\ кандидат педагогічних наук, доцент \\ декан факультету підвищення кваліфікації педагогічних кадрів, \\ Донецький обласний інститут післядипломної педагогічної освіти, \\ м. Краматорськ, Україна \\ ORCID ID 0000-0002-9276-3173 \\ takolgan@ippo.dn.ua

\section{Олена Колган} \\ кандидат філологічних наук, доцент \\ доцент кафедри української мови та літератури, \\ ДВНЗ «Донбаський державний педагогічний університет», \\ м. Слов'янськ, Україна \\ ORCID ID 0000-0002-2155-4155 \\ ovkolgan@gmail.com
}

\begin{abstract}
Анотація. У статті розглянуто особливості цифровізації як суспільного явища. Визначено вплив цифровізації на освітні та управлінські процеси, що відбуваються у закладах загальної середньої освіти. Опрацьовано сутність системи управління організацією, іiі елементів та принципів. Проаналізовано зв'язок поняття «система управління закладом загальної середньої освіти» 3 теорією організації як наукою. Запропоновано модель системи управління закладом загальної середньої освіти із застосуванням сучасних цифрових освітніх інструментів. Розглянуто функції управління та приклади використання цифрових технологій під час їх виконання. Визначено ключовий перелік онлайн-сервісів забезпечення ефективної комунікації між керуючою та керованою підсистемами закладу загальної середньої освіти. Досліджено особливості цифровізації окремих етапів прийняття управлінських рішень у закладах загальної середньої освіти.
\end{abstract}

Ключові слова: цифровізація освіти; цифровізація управлінських процесів; система управління закладом загальної середньої освіти; моделювання; функції управління; комунікації; прийняття управлінських рішень.

(ㄷ ДВНЗ «Донбаський державний педагогічний університет» 
Постановка проблеми в загальному вигляді. Цифрова трансформація створює нові унікальні можливості для розвитку суспільства. Особливе місце в цих процесах займає освітня діяльність, що складається 3 освітнього та управлінських процесів. Останні роки у зв'язку з пандемією COVID-19 впровадженню онлайн-технологій в освітній процес приділяється значна увагу. Управлінські процеси закладів освіти, зокрема загальної середньої, також потребують цифрових трансформацій, результатом яких будуть підвищення продуктивності праці, економія часу, відхід від паперових носіїв тощо.

Аналіз останніх досліджень і публікацій. Дослідженню систем управління організації, їх моделюванню, аналізу ii підсистем та елементів, функцій управління тощо було присвячено багато праць провідних зарубіжних та українських вчених, серед яких: М. Мескон, М. Альберт, Ф. Хедоурі, І. Борисенко, В. Глушков, Н. Дикань, В. Іваненко, М. Клименюк, О. Кузьмін, Г. Монастирський, Р. Павлова, В. Старикова, Г. Титаренко, В. Уткін та інші. Водночас вагомий внесок в дослідження питань використання цифрових технологій в управлінні закладами освіти внесли такі українські вчені, як Н. Василенко, І. Воротникова, В. Гладкова, О. Захар, С. Одайник, А. Панченко, Г. Панченко, В. Стойкова, Т. Тихонова та інші.

Формулювання цілей статті (постановка завдання). Аналіз наукових та практичних праць, присвячених проблемам функціонування освітнього менеджменту в закладах загальної середньої освіти, показав, що питання теоретичного, методичного та практичного характеру щодо впровадження сучасних цифрових технологій в систему управління закладами загальної середньої освіти закладами освіти 3 метою підвищення іiі ефективності залишаються недостатньо розробленими та дослідженими. Метою даної статті $\epsilon$ побудова моделі системи управління закладом загальної середньої освіти, базуючись на теорії організації, 3 використанням цифрових освітніх інструментів.

Результати дослідження. Сучасною тенденцією розвитку суспільства $\epsilon$ цифровізація. Цей процес передбачає впровадження цифрових технологій в усі сфери життя: від взаємодії між людьми до промислових виробництв, від предметів побуту до дитячих іграшок, одягу тощо. У широкому розумінні цифровізація означає перехід діяльності з реального світу у світ віртуальний (онлайн).

Сьогодні ключовими цифровими технологіями $\epsilon$ Інтернет речей, роботизація та кіберсистеми, штучний інтелект, великі дані, безпаперові 
технології, адитивні технології (3D-друк), хмарні та туманні обчислення, безпілотні та мобільні технології, біометричні, квантові технології, технології ідентифікації, блокчейн тощо (Економічна стратегія України 2030, б. д.).

За оцінками експертів Українського інституту майбутнього впровадження цифрових технологій створює переваги у різних сферах повсякденного життя. Наприклад, в країнах-лідерах цифрових трансформацій позитивно впливає на:

- енергоефективність: зростання до $200 \%$;

- ефективність використання ресурсів: зростання до 400 \%;

- продуктивність роботи працівників: зростання до 50 \%;

- робочі місця для кваліфікованих працівників: зростання до 40 \%;

- вартість обслуговування та супроводження: зменшення до 40 \% тощо (Економічна стратегія України 2030, б. д.).

Однією $з$ ключових галузей, в якій ефект від цифрової трансформації $є$ найбільш відчутним, вважається освіта, зокрема загальна середня. Однак під час таких трансформацій система загальної середньої освіти зіткнулась 3 певними викликами, що були визначені експертами проєкту «Цифрова адженда України - 2020» у 2016 році:

- українська середня школа потребує кардинальних трансформацій, адже поки це інституція, котра продовжує існувати майже на тих самих традиціях та підходах, що і 100 років тому;

- небажання дітей навчатися, вони втрачають інтерес до предметів, бажання пізнавати та досліджувати, а відвідини шкільних занять перетворюються на нудну формальність;

- середні школи має готувати громадян, що будуть жити та творити у швидкоплинному світі;

- принцип «знати все» змінюється на принцип «знати, як навчатися протягом життя та стати самореалізованим та конкурентноздатним», а робота 3 інформацією на принципах «запам'ятовування» поступово втрачає сенс через розвиток Інтернет;

- невідворотність подальшої цифровізації як глобального та національного явища, реформування середньої освіти має відбуватись відповідно з урахуванням потреб розвитку цифрового суспільства;

- цифрові технології дозволяють зробити процес навчання мобільним, диференційованим та індивідуальним;

- цифрові технології дають вчителю нові можливості, дозволяючи разом 3 учнем отримувати задоволення від захопливого процесу спілкування та пізнання (Цифрова адженда України - 2020, 2016, с. 22-24). 
За підсумками 2016 року стан впровадження цифрових технологій в середніх школах характеризувався наступними проблемами:

- 95 \% шкіл використовують комп’ютерну техніку (робочі станції), що була вироблена та поставлена у період 2000-2011 року, тобто на 100 \% є морально застарілою;

- пропорція кількості учнів на комп’ютер складає 27:1 (для прикладу, в Європі ця пропорція складає $3: 1)$;

- комп'ютерні класи, що знаходяться в основному в кабінетах інформатики, не можуть через «стаціонарність» зробити увесь навчальний процес «технологічним»;

- звичним явищем $є$ використання неліцензійного програмного забезпечення;

- підключення шкіл до мережі Інтернет в багатьох випадках здійснюється за ініціативи батьків та громади, класи зазвичай не підключаються взагалі тощо (Цифрова адженда України - 2020, 2016, с. 24).

Поштовх до цифровізації загальної середньої освіти відбувся у 2020 році, коли розпочалась пандемія COVID-19. Саме тоді освітній процес перейшов терміново від традиційного (оффлайн) формату до дистанційного (онлайн) навчання, а потім до використання змішаного навчання, тобто поєднання першої та другої форм.

Необхідно зазначити, що цифрові освітні технології, зокрема, хмарні технології, можуть бути застосовані не тільки в освітньому процесі, а й в управлінських процесах закладу освіти. Визначимось із сутністю управлінських процесів. Їх сутність визначена у Порядку проведення інституційного аудиту закладів загальної середньої освіти, затвердженого наказом Міністерства освіти і науки України 09 січня 2019 року № 17 (у редакції наказу Міністерства освіти і науки України від 30 квітня 2021 року № 493). Отже, управлінський процес - це діяльність керівника закладу освіти, його заступників та органів управління закладу освіти, спрямована на досягнення цілей закладу освіти (відповідно до стратегії розвитку закладу освіти, його річного плану роботи) шляхом формування, прийняття та реалізації управлінських рішень (Про затвердження Порядку проведення інституційного аудиту закладів загальної середньої освіти, 2021).

На думку І. Воротникової «впровадження цифрових технологій в усі ланки освітнього процесу ініціює удосконалення механізмів управління школою на основі: 
- удосконалення відбору змісту, методів і організаційних форм навчання та виховання (дистанційна, змішана), що відповідають завданням розвитку особистості в умовах карантинних обмежень, зокрема навчання на відстані;

- створення єдиного інформаційно-освітнього середовища закладу освіти з можливостями захисту персональних даних та дотриманням академічної доброчесності;

- використання автоматизованих систем управління навчанням (LMS) та змістом навчання (CMS);

- використання автоматизованих банків даних навчально-педагогічної інформації, створення медіатек, репозиторіїв тощо;

- використання інформаційно-методичних матеріалів, електронноосвітніх ресурсів з досвіду роботи керівників закладів освіти України та світу;

- використання комунікаційних мереж для обміну інформацією, організації зворотного (керівник школи - вчитель - учні - батьки) та зовнішнього зв’язку (керівники закладів освіти між собою, з працівниками управлінь освіти і Департаментом освіти i науки, іншими організаціями, міжнародними партнерами тощо);

- створення та використання комп'ютерних тестів чи методик діагностики, моніторингу та контролю роботи закладу освіти, рівня знань учнів, професійного розвитку педагогічних працівників тощо» (Воротникова, 2021, c. 330).

Водночас актуальним залишається питання побудови цілісної системи управління закладом загальної середньої освіти із застосуванням цифрових інструментів.

Слід відзначити, що на даний час не існує загальноприйнятого та сталого визначення поняття «система управління закладом загальної середньої освіти» й тому це питання залишається дискусійним. Закон України «Про повну загальну середню освіту» містить статтю 36, що має назву «система управління закладом загальної середньої освіти». Але закон не містить визначення сутності цього поняття (Про повну загальну середню освіту, 2021, ст. 36).

Результати проведеного дослідження свідчать про те, що визначення поняття «система управління закладом загальної середньої освіти» має базуватись на засадах такої науки як теорія організації. На думку відомих вчених-економістів М. Х. Мескона, М. Альберта, Ф. Хедоурі, організацію розглядають як групу людей, діяльність яких свідомо координується для досягнення загальної цілі або цілей (Мескон, Альберт \& Хедоури, 1998, с. 40). Заклад загальної середньої освіти об’єднує різних учасників освітнього процесу, 
дії яких координуються з метою забезпечення всебічного розвитку, навчання, виховання, виявлення обдарувань, соціалізації особистості, яка здатна до життя в суспільстві та цивілізованої взаємодії з природою, має прагнення до самовдосконалення і здобуття освіти упродовж життя, готова до свідомого життєвого вибору та самореалізації, відповідальності, трудової діяльності та громадянської активності, дбайливого ставлення до родини, своєї країни, довкілля, спрямування своєї діяльності на користь іншим людям і суспільству, а також формування життєвих компетентностей. Тому можна стверджувати, що заклад загальної середньої освіти є певною організацією, що потребує системи управління.

У своїй статті Р. Павлова, В. Іваненко, посилаючись на думку М. Клименюка, звертають увагу на те, що «система управління визначається як така, що має дві тісно пов'язані між собою основні складові частини, які утворюються з елементів системи і мають назву підсистем: орган управління та об'єкт управління» (керуюча та керована системи) (Павлова \& Іваненко, 2020, c. 62). Більш чітке визначення системи управління наводить вчений-економіст Г. Монастирський: «система управління організацією включає сукупність всіх служб організації, всіх підсистем та комунікацій між ними, а також процесів, що забезпечують функціонування організацією» (Монастирський, 2014, с. 133).

Виходячи 3 вищезазначеного, складовими системи управління закладом загальної середньої освіти $\epsilon$ :

- безпосередньо сам процес управління, що базується на відповідних функціях;

- керуюча підсистема (засновник (засновники) або уповноважений ним (ними) орган, керівник закладу освіти, педагогічна рада та вищий колегіальний орган громадського самоврядування закладу освіти) та керована підсистема (педагогічні працівники, учні, батьки), комунікації між ними;

- механізм прийняття управлінських рішень.

На думку Г. Монастирського організацію як керовану систему характеризують три основні принципи: обгрунтованість, цілеспрямованість та моделювання (Монастирський, 2014, с. 137). Саме принцип моделювання свідчить про те, що організація як складна система може бути представлена багатоманіттям моделей, кожна з яких відображає певну грань їі суті.

Вдалим рішенням для закладу загальної середньої освіти є впровадження вже розробленої автоматизованої системи управління. Однак, такий підхід має свої недоліки. Придбання розробленої системи потребує фінансування. Вона 
вимагає постійного забезпечення, витрат часу на ознайомлення та навчання учасників освітнього процесу, а також їх готовності працювати в такій системі. Кожен заклад загальної середньої освіти є унікальним та специфічним, тому розроблену автоматизовану систему управління необхідно додатково налаштовувати на його потреби.

Дієвою альтернативою $є$ побудова моделі системи управління 3 використанням вже відомих, опрацьованих та, як правило, безкоштовних (недорогих) цифрових освітніх інструментів. Так, за результатами онлайнанкетування учасників освітнього процесу, проведенного Державною службою якості освіти України з 02 по 09 лютого 2021 року щодо організації дистанційного навчання у закладах загальної середньої освіти в 2020/2021 навчальному році, керівники шкіл вказали, що організовують єдиний інформаційний простір переважно на безкоштовних платформах: G Suite for Education Google Classroom, Microsoft Teams, Human, Moodle та ін. (Аналітична довідка щодо організації дистанційного навчання у закладах загальної середньої освіти в 2020/2021 навчальному році, б.д.). Слід зазначити, що розробка альтернативного підходу потребує комплексного рішення, що оптимізує реалізацію та підвищить ефективність управлінських процесів.

Далі буде розглянуто модель системи управління закладом загальної середньої освіти, в якій кожен $з$ елементів системи поєднуються з відповідними цифровими освітніми інструментами, важливою особливістю яких $\epsilon$ їх функціонування як на стаціонарних цифрових пристроях, так й мобільних. У моделі, що пропонується, буде використано розроблену раніше та доопрацьовану концепцію впровадження цифрових інструментів в систему управління закладом загальної середньої освіти (Правдивцев \& Шевченко, 2019, c. 134). Перший елемент системи - процес управління - буде базуватись на підході М. Х. Мескона, М. Альберта і Ф. Хедоурі (1998) щодо визначення основних функцій управління: планування, організація, мотивація та контроль.

Основним інструментом планування діяльності у закладі загальної середньої освіти має стати цифровий інструмент Google Календар. Він $\epsilon$ безкоштовним та потужним інструментом тайм-менеджменту, що дозволяє планувати події та заходи, запрошувати та приєднувати до них інших осіб. Сервіс інтегрується 3 різними цифровими інструментами, зокрема засобами відеоконференцзв’язку. Цифровий інструмент Google Календар містить гнучкий механізм нагадування про заплановані події. Тому його доцільно використовувати у закладі загальної середньої освіти для планування засідань педагогічної ради, різноманітних нарад, таким чином відмовившись від 
паперових оголошень. Також інструмент Google Календар може бути використано для складання цифрового розкладу занять з можливістю надання доступу до нього для всіх учасників освітнього процесу або розміщення на офіційному Інтернет-сайті закладу освіти.

Важливим інструментом для планування індивідуальної роботи є сервіс Google Завдання. Він дозволяє кожному працівнику скласти перелік необхідних власних завдань та встановити кінцевий термін їх виконання. Сервіс інтегрується автоматично 3 Google Календарем та постійно нагадує про необхідність виконання завдань у визначені терміни. Останнім цифровим інструментом планування в моделі системи управління, що пропонується, є сервіс Google Keep. Використовуючи цей сервіс, кожен працівник має можливість створити план роботи (або чек-ліст) у вигляді нотатків. У разі необхідності можна приєднати до виконання плану роботи інших працівників. Сервіс Google Keep так само інтегрується з Google Календарем та включає механізм нагадування.

Отже, використання перелічених сервісів дозволяє значно підвищити ефективність планування діяльності закладу загальної середньої освіти та помітно автоматизувати реалізацію такої функції.

Як відомо, основними складовими організаційного процесу є: поділ праці; департаменталізація; делегування повноважень; створення механізмів координації; скалярний процес. У запропонованій моделі системи управління департаменталізацію та делегування повноважень доцільно здійснювати 3 використанням сервісів Google Контакти та Google Групи.

Саме використання сервісу Google Контакти дозволяє ідентифікувати кожного працівника організації, акумулювати інформацію про його посаду та структурний підрозділ, створити онлайн-книгу контактів, позначити день народження тощо. Інструмент $є$ гнучким та дозволяє налаштовувати додаткові поля. Наприклад, для педагогічних працівників є можливість додати дані про кваліфікаційну категорію та педагогічне звання, рік проходження сертифікації, покликання на професійний блог тощо. 3 метою автоматизації наповнення бази контактів необхідно поєднати роботу декількох сервісів у послідовний процес:

- cepвic Google Форми: створення форми 3 полями відповідно до структури сервісу Google Контакти;

- cepвic Google Таблиці: вивантаження файлу-таблиці контактів з форми 3 розширенням *.csv;

- cервіс Google Контакти: імпорт файлу-таблиці контактів. 
У свою чергу, сервіс Google Групи дозволяє об’єднувати акаунти в групи 3 метою масової розсилки або для спільного обговорення проблемних питань 3 можливістю модерації. Наприклад, у закладі загальної середньої освіти на рівні керуючою підсистеми можуть бути створені групи адміністрації, педагогічної ради, на рівні керованої підсистеми - групи методичних об'єднань, батьків, класи учнів, а також окрема група всього закладу освіти.

Механізм координації найкраще реалізується через сервіси для спільної роботи, серед яких Google Документи, Google Таблиці, Google Презентації. Такі інструменти пришвидшують процес створення спільного документу, таблиці або презентації, дозволяють бачити зміни, що вносяться та ким вносяться, реалізують механізм пропонування змін з подальшим їх узгодженням. Сервіси для спільної роботи містять можливості спільної комунікації під час роботи над одним документом великої кількості працівників шляхом спілкування в чаті сервісів.

Поділ праці здійснюється в сервісі Google Chat. Оновлений механізм роботи сервісу дозволяє створити кімнати для створених груп або окремих контактів та шляхом інтеграції з сервісом Google Завдання визначати зміст завдання, приєднати необхідні інформаційні матеріали, встановити виконавців та терміни виконання. Скалярний процес як вид організаційної діяльності менеджера використовується при організації комунікацій у системі управління і тому буде розглянуто окремо. Отже, реалізація перелічених можливостей сервісів значно покращить організаційну складову системи управління будьякого закладу освіти

Наступна функція управління - мотивація. Одним із способів стимулювання працівників 3 використанням цифрових освітніх технологій $\epsilon$ налаштування автоматизованого привітання працівника 3 днем народження. Для реалізації такого процесу необхідно використати розширення GMASS для сервісу Gmail, створити корпоративний лист-привітання, скласти список контактів для розсилки з відповідними датами у форматі таблиці та прикріпити iї до вищезазначеного розширення.

Іншим способом мотивації всіх учасників освітнього процесу $\epsilon$ налагодження зворотного зв'язку з метою більшого розуміння їх проблем та ставлення до освітнього процесу, прийнятих рішень адміністрацією. У даному випадку доцільно використовувати сервіс Google Форми. Такий інструмент не тільки дозволить у зручний спосіб зібрати результати опитування, а й здійснить їх обробку, що значно економить час на досягнення поставленої мети в опитуванні. 
Контрольна функція в системі управління закладом загальної середньої освіти реалізується в таких сервісах, як Google Завдання та Google Keep. Виконавець завдання має можливість поставити необхідну позначку у завданні (або нотатку) відповідного цифрового інструменту й таким чином повідомити керівника про хід виконання завдання в режимі онлайн.

Другим елементом в системі управління організацією $є$ комунікації. Як зазначають Н. Дикань і І. Борисенко, «комунікація - процес обміну інформацією та змістовим значенням між двома або більше людьми (тобто передача інформації)» (Дикань \& Борисенко, 2008, с. 298). Оскільки заклад загальної середньої освіти є організацією, тобто структурованим типом відносин між людьми, то його діяльність значною мірою залежить від якості комунікацій.

Під час цифровізації управлінських процесів та покращення ефективності взаємодії між керованою та керуючою підсистемами закладу загальної середньої освіти доцільно використовувати сервіси для проведення відеоконференцій: Google Meet, Zoom, Microsoft Teams, Jitsi Meet. Особливістю саме цих сервісів $є$ можливість інтегрувати їх з Google Календарем й, таким чином, відеозустрічі організовувати вже на етапі планування діяльності. Для вирішення оперативних питань необхідно використовувати месенджер Google Chat.

Третім елементом системи управління закладом загальної середньої освіти $\epsilon$ підсистема прийняття рішень. У загальному вигляді процес прийняття управлінських рішень містить наступні етапи: збір інформації, аналіз інформації, діагностування проблеми, визначення обмежень, підготовка альтернативних рішень, прийняття рішення, реалізація рішення та оцінка результатів.

На даний час процес прийняття рішень $є$ найбільш складним в питанні цифровізації, оскільки не на кожному його етапі можуть бути задіяні цифрові інструменти, а реалізація деяких етапів залежить напряму від людини-керівника. Показовим є використання цифрових інструментів під час визначення обмежень та підготовки альтернативних рішень. Так, кожного року у закладі загальної середньої освіти виникає проблема складання розкладу навчальних занять. Для вирішення такого завдання можна використати інструмент Asc Timetables. Цей продукт є генератором розкладу за умови внесення в програму інформації про час занять, аудиторний фонд, викладачів тощо, тобто різних обмежень. Система автоматично складає можливі варіанти розкладу, з яких керівник може обрати найбільш оптимальний. Аналогічно для інших проблем можна використовувати цифрові інструменти. Наприклад, скласти проект кошторис закладу освіти 3 пов'язаними аналітичними таблицями, що містять розрахунки видатків, в сервісі 
Google Таблиці. Змінюючи параметри аналітичних таблиць, можна побачити, що буде відбуватися з проектом кошторису.

Висновки $з$ дослідження і перспективи подальших розвідок у цьому напрямі. Таким чином, цифровізація залишається ключовим трендом, що охоплює різні сфери життєдіяльності людини i, перш за все, освіту. Використання цифрових інструментів можливо не лише в освітньому процесі, а й в управлінні закладом освіти, зокрема загальної середньої. Разом 3 тим запровадження таких технологій потребує системності 3 огляду на функціонування закладу загальної середньої освіти як організації. Вирішення такого завдання можливо завдяки моделюванню системи управління закладом освіти з використання цифрових освітніх технологій, що охопить такі елементи системи, як безпосередньо процес управління, комунікації та механізм прийняття рішень. Реалізація такої моделі дозволить закладам загальної середньої освіти економити час та кошти, підвищити продуктивність діяльності, сприяти сталому розвитку.

Перспективи подальших досліджень полягають у вивченні нових тенденцій у цифровізації діяльності закладів освіти; пошуку нових цифрових освітніх інструментів, що можуть бути задіяні в системі управління закладом загальної середньої освіти; більш поглибленому дослідженні процесів прийняття управлінських рішень з використанням цифрових технологій.

\section{СПИСОК ВИКОРИСТАНИХ ДЖЕРЕЛ}

1. Аналітична довідка щзодо організаиії дистаниійного навчання у закладах загальної середньої освіти в 2020/2021 навчальному роиі. (б. д.). Державна служба якості освіти. Взято 3 https://sqe.gov.ua/wp-content/uploads/2021/07/Analitichna-dovidka-lyutiy-2021.pdf

2. Воротникова, I. П. (2021). Розділ 5. Цифрові інструменти для адміністрування освітнього процесу. Дистанційне навчання: виклики, результати та перспективи: Порадник II. 3 досвіду роботи освітян міста Київа. Київ, Україна: Київ. ун-т ім. Б. Грінченка.

3. Дикань, Н. В., \& Борисенко, I. І. (2008). Менеджмент. Київ, Україна: Знання.

4. Економічна стратегія України 2030. (б. д.). Український інститут майбутнього. Взято 3 https://strategy.uifuture.org/index.html.

5. Мескон, М. Х., Альберт, М., \& Хедоури, Ф. (1998). Основы менеджмента. Москва: Дело.

6. Монастирський, Г. Л. (2014). Теорія організації. Тернопіль, Україна: ТНЕУ.

7. Павлова, Р. К., \& Іваненко, В. В. (2020). Моделювання структури системи управління організацією. Вчені записки ТНУ імені В. І. Вернадського. Серія: Економіка $i$ управління, 70 (4), 61-67. https://doi.org/10.32838/2523-4803/70-4-11.

8. Правдивцев, П. А., \& Шевченко, К. М. (2019). Концепція впровадження цифрових сервісів в систему управління закладами загальної середньої освіти. Сучасний освітньоінформаційний простір для формування сочіально активної та професійно зорієнтованої особистості: виклики, досягнення, перспективи розвитку умовах Нової української иколи (с. 133-137). Видавець ПП Лисенко М. М. 
9. Про затвердження Порядку проведення інституційного аудиту закладів загальної середньої освіти, Наказ Міністерства освіти і науки України № 17 (2021) (Україна). Взято 3 https://zakon.rada.gov.ua/laws/show/z0250-19.

10. Про повну загальну середню освіту, Закон України № 463-IX (2021) (Україна). Взято 3 https://zakon.rada.gov.ua/laws/show/463-20 Україна».

11. Цифрова адженда України - 2020. (2016). Київ, Україна: ГО «ХайТек Офіс

\title{
MODELING OF GENERAL SECONDARY EDUCATION INSTITUTION MANAGEMENT SYSTEM USING DIGITAL EDUCATIONAL TECHNOLOGIES
}

\author{
Pavlo Pravdyvtsev \\ Candidate of Economic Sciences,
}

Senior Lecturer at The Department of Management and Administration,

Donetsk In-Service Teacher Training Institute,

Kramatorsk Ukraine

ORCID ID 0000-0002-1593-2412

p.pravdivtsev@ippo.dn.ua

Tetyana Kolgan

Candidate of Pedagogical Sciences, Docent

Dean of The Faculty of Pedagogical Training,

Donetsk In-Service Teacher Training Institute,

Kramatorsk Ukraine

ORCID ID 0000-0002-9276-3173

takolgan@ippo.dn.ua

\section{Olena Kolgan}

Candidate of Philological Sciences, Docent

Associate Professor at the Department of Ukrainian Language and Literature,

SHEI "Donbas State Pedagogical University"

ORCID ID 0000-0002-2155-4155

ovkolgan@gmail.com

\begin{abstract}
The article considers the model of the management system of a secondary education institution with the integration of modern digital tools and the impact of digital changes on the educational and managerial processes taking place in the secondary education system of Ukraine. The authors of the article note that the COVID-19 pandemic has accelerated the introduction of online technologies in the educational process, but the use of digital tools in the management of educational institutions is still insufficient.

Analyzing scientific works on the management systems of the organization and digital transformations in them, the authors signify an insufficient of publications on the digitalization of management systems of secondary education institutions.
\end{abstract}




\section{П. ПРАВДИВЦЕВ,Т. КОЛГАН, О. КОЛГАН \\ Моделювання системи управління закладом загальної середньої освіти з використанням цифрових освітніх технологій}

The scientific article consists of three parts. The first part is devoted to the features of digital transformations in education in Ukraine and their problems. The second part defines the essence of the management system of general secondary education, based on the theory of organization, and analyzes the structure of such a system and the principles of its operation. In the third part, the authors propose a model of the management system of general secondary education institutions with the addition of digital educational tools.

The results of the study allow the authors to assert that digitalization is an important trend for the educational sector of Ukraine. It is noted that this process should be implemented simultaneously in educational and management processes. The use of digital technologies in the management of general secondary education should be systemic. A model of an educational institution management system in which digital educational tools are integrated is proposed. It covers key elements of the system, including the management process, communication and decision-making mechanism. The proposed model of the management system allows to save time and money, increase the productivity of the educational institution, contributes to the implementation of the concept of sustainable development.

Key words: digitalization of education; digitalization of management processes; secondary education institution management system; modeling; management functions; communications; making management decisions.

\section{REFERENCES}

1. Analytical reference on the organization of distance learning in general secondary education institutions in the 2020/2021 academic year. (n. d.). State Service for Education Quality. Retrieved from https://sqe.gov.ua/wp-content/uploads/2021/07/Analitichna-dovidka-lyutiy2021.pdf.

2. Vorotnykova, I. P. (2021). Section 5. Digital Tools for the Administration of the Educational Process. Distance Learning: Challenges, Results and Prospects: Guide II. From the experience of educators of Kyiv. Kyiv, Ukraine: Kyiv Borys Hrinchenko University.

3. Dykan, N. V., \& Borysenko, I. I. (2008). Management. Kyiv, Ukraine: Znannia.

4. Economic Strategy of Ukraine 2030. (n. d.). Ukrainian Institute of the Future. Retrieved from https://strategy.uifuture.org/index.html.

5. Meskon, M. H., Albert, M., \& Hedouri, F. (1998). Fundamentals of Management. Moscow: Delo.

6. Monastyrskyi, H. L. (2014). Organization Theory. Ternopil, Ukraine: TNEU.

7. Pavlova, R. K., \& Ivanenko, V. V. (2020). Modeling the Structure of the Organization Management System. Scientific Notes of TNU named after V.I. Vernadskys. Series: Economics and Management, 70 (4), 61-67. https://doi.org/10.32838/2523-4803/70-4-11

8. Pravdyvtsev, P. A., \& Shevchenko, K. M. (2019). The Concept of Digital Services Introduction in the Management System of General Secondary Education Institutions. Modern Educational and Information Space for the Formation of Socially Active and Professionally Oriented Personality: Challenges, Achievements, Prospects for the Development of the New Ukrainian School (pp. 133-137). Kharkiv, Ukraine: Vyd. Lysenko M. M.

9. On Approval of the Procedure for Conducting an Institutional Audit of General Secondary Education Institutions, Order of the Ministry of Education and Science of Ukraine № 17 (2021). Ukraine. Retrieved from https://zakon.rada.gov.ua/laws/show/z0250-19.

10. On Complete General Secondary Education, Law of Ukraine № 463-IX (2021). Ukraine. Retrieved from https://zakon.rada.gov.ua/laws/show/463-20.

11. Digital Agenda of Ukraine - 2020. (2016). Kyiv, Ukraine: HiTech Office Ukraine.

Матеріали надійшли до редакції 09.09.2021 р. 